\title{
A Review on Fungal Fermented Cassava Pulp as a Cheap Alternative Feedstuff in Poultry Ration
}

\author{
Sugiharto Sugiharto \\ Department of Animal Science, Faculty of Animal and Agricultural Sciences, Diponegoro University, Semarang, Central Java, 50275, Indonesia \\ Corresponding author's Email: sgh_undip@yahoo.co.id
}

Received: 07 Jan 2019

Accepted: 11 Feb 2019

\begin{abstract}
In order to reduce the production cost, cassava pulp has been incorporated in chicken diets as an energy source. However, the use of such agro-industrial by-product may be confined by its higher fibre and lower protein contents. Improving the nutritional characteristics (lowering fibre and increasing protein content) through fungal solid state fermentation may be conducted to increase the inclusion level of cassava pulp in chicken rations. Apart from an energy source, fungal fermented cassava pulp (FCP) may also exert a beneficial effect on intestinal health of chickens, although further studies are needed to explore the functional benefit of FCP on chicken health.
\end{abstract}

Keywords: Chicken diet, Energy source, Fermented tapioca by-product, Fungal solid-state fermentation

\section{INTRODUCTION}

Feed cost has been a major component in chicken production, representing about $70 \%$ of the total cost of production. Generally, chicken diets are composed of several feedstuffs, and that energy-rich feedstuffs such as maize constitute more than half of the diets. Owing to this fact, any increase in the price of maize can potentially increase the chicken production cost and consequently, reduce the profit margin of farmers. Nutritionists are now exploring for unconventional energy-rich feedstuffs that may be used to reduce the proportion of maize in chicken rations. Among the alternative feedstuffs, cassava pulp has frequently been incorporated in chicken rations as a source of energy. On the other hand, the incorporation of such agro-industrial by-product in chicken rations may be limited by the high and low contents of fibre and protein, respectively (Khempaka et al., 2009). Fungal solid state fermentation could be one of the methods to improve the nutritional qualities and thus increase the inclusion level of cassava pulp in chicken rations (Khempaka et al., 2014; Sugiharto et al., 2017a). This present mini review elaborates the potential of fungal Fermented Cassava Pulp (FCP) as an energy-rich alternative feed ingredient for chickens.
Cassava pulp as an energy-rich alternative feedstuff for chickens

As a response to the increased price of maize, nutritionists are currently searching some cheap energyrich alternative to partially replace the use of maize in chicken diets. As a by-product of tapioca industry, cassava pulp is quite cheap and abundantly available throughout the year, particularly in tropical countries. Cassava pulp contains true metabolizable energy (TME) of about 2,484 $\mathrm{kcal} / \mathrm{kg}$ energy, therefore, it may be potential as an energy source in chicken rations (Khempaka et al., 2009). On the other hand, it should be noticed that the nutritional qualities of cassava pulp may vary depending on the varieties of cassava, manufacturing process to produce tapioca, the process of drying and contamination (with fibre, sand and soil) (Chauynarong et al., 2015).

Dried cassava pulp has been incorporated as an energy source both in broiler and laying hen diets (Table 1). Nevertheless, its maximum inclusion level differs in broiler and laying hen diets. Dried cassava pulp may be incorporated at higher levels in laying hen (15-20\%) as compared to that in broiler diets (Maximum 11\%). Similar with this case, King and Zeidler (2004) documented that 
dried tomato pomace (contains $31 \%$ fibre) may be incorporated at $15 \%$ in laying hen diets, while such pomace may only be included in broiler rations at the maximum of 5\%. The better capability of laying hens in degrading fibre than of broilers seems to be the reason for the higher fibre digestibility (and thus intake of fibre-rich feedstuffs) in laying hens. Moreover, laying hens seem to have lower energy requirement compared to broiler chickens. This makes laying hens more tolerant to cassava pulp (Diarra and Devi, 2015). Within each broiler and laying hens, the variations in the optimal dietary levels of cassava pulp also existed. In such case, several factors may determine the variation, including the nature (e.g., nutritional composition) of cassava pulp, dietary composition, energy to protein ratio of rations, strains of chickens and other experimental conditions.

Aside from the high energy content, cassava pulp generally contains high and low contents of fibre (13.6\%) and protein (1.98\%), respectively (Khempaka et al., 2009). According to Morgan and Choct (2016), most of the fibre in cassava pulp is counted as insoluble fibre. The latter properties may, therefore, limit the use of cassava pulp in poultry rations, as poultry has a very limited capacity in degrading the insoluble fibre. High fibre fraction in cassava pulp may also increase the bulkiness of the diet and therefore limit the capacity of the digestive tract of chickens. This condition may eventually reduce palatability and feed intake in chickens (Khempaka et al., 2009). To elevate the dietary inclusion level of cassava pulp, supplementation of enzymes have been conducted. Khempaka et al. (2018) have recently supplemented dried cassava pulp with mixed enzymes containing cellulase, glucanase and xylanase in laying hens. Such enzyme supplementation could increase the inclusion level of dried cassava pulp from $20 \%$ (Khempaka et al., 2016) to $30 \%$ (Khempaka et al., 2018) in laying hen diets. The activity of enzymes in degrading the fibre fraction of cassava pulp may increase the digestibility of such feed ingredient and thus increase the feed intake of chickens (Khempaka et al., 2018).

Table 1. The use of dried cassava pulp in chicken diets

\begin{tabular}{ll}
\hline References & Findings and recommendations \\
\hline Khempaka et al. (2009) & $\begin{array}{l}\text { Dried cassava pulp should be limited to } 8 \% \text { or less, as higher inclusion level may compromise the growth } \\
\text { performance of broiler chickens. }\end{array}$ \\
\hline Kumsri et al. (2009) & Dietary inclusion of 10\% dried cassava pulp reduced weight gain of broiler chickens. \\
\hline Ali-Mursyid et al. (2010) & $\begin{array}{l}\text { Dried cassava pulp may be incorporated in broiler rations at a maximum of 11\%, higher inclusion level } \\
\text { may be detrimental for the growth of broilers. }\end{array}$ \\
\hline Tang et al. (2012) & Feeding dried cassava pulp at a level of 25\% resulted in poor growth performance in broiler chickens. \\
\hline Triprugsachart et al. (2007) & $\begin{array}{l}\text { Feeding dried cassava pulp up to 15\% represented no detrimental impact on egg production of laying } \\
\text { hens. }\end{array}$ \\
\hline Chauynarong et al. (2010) & $\begin{array}{l}\text { Dietary incorporation of dried cassava pulp up to 15\% had no deleterious effect on egg production of } \\
\text { laying hens. }\end{array}$ \\
\hline Khempaka et al. (2016) & $\begin{array}{l}\text { Dried cassava pulp can be included up to 20\% in laying hen rations with no negative impact on productive } \\
\text { performance, nutrient digestibility, and egg quality. }\end{array}$ \\
\hline Khempaka et al. (2018) & $\begin{array}{l}\text { Dried cassava pulp supplemented with mixed enzymes (cellulase, glucanase and xylanase) may be } \\
\text { included in laying hen feeds up to 30\% with no detrimental effects on nutrient digestibility, productive } \\
\text { performance and egg quality. }\end{array}$ \\
\hline
\end{tabular}

\section{Fungal fermentation to improve the nutritional characteristics of cassava pulp}

Fermentation is a simple process using microorganisms to break down the complex substrates into simpler components (Sugiharto and Ranjitkar, 2019). Eventually, the degraded compounds maybe utilized maximally by the chickens. Depending on the microorganisms involved, supplements added, duration of the fermentation process and other fermentation conditions, there is a slight variation in the improvement of the nutritional quality of cassava pulp particularly with regard to protein and fibre contents. It appears from the documented studies that fungi (Filamentous fungi and yeast) are the most common microorganisms employed to ferment cassava pulp. The definite reason for such preference is not specifically known. There are several traits belong to fungi that may be exploited to improve the nutritional properties of cassava pulp, one of which is its fibrinolytic activity. A study by Mustafa et al. (2016) noticed that treatment with fungi was capable of degrading 
the insoluble fibre (lignin and hemicellulose) resulting in reduced fibre content of the substrates. Such fibre degradation may be facilitated by the activity of extracellular cellulases produced by the fungi (Bhardwaj et al., 2017). The cellulolytic activity of the fungi may also transform the cellulosic compounds into protein, and therefore increase the protein content of materials. In such case, the conversion of fibre into protein-rich fungal biomass may be responsible for the increased protein content of the fungal fermented products (Asadollahzadeh et al., 2018). In addition, Bayitse et al. (2015) suggested that simple sugars may also be metabolized to protein resulting in an increase in protein content of the fermented products. Apart from the improved fibre and protein contents, fermentation has been known to result in the reduction of Hydrogen Cyanide (HCN) (Diarra and Devi, 2010).
To increase the protein content of FCP, supplementation using urea during fermentation has commonly been conducted (Table 2). During the fermentation process, urea may be used as a nitrogen source for the fungal growth (Bayitse et al., 2015). Such an increase in fungal biomass may thereby increase the protein content of the fungal fermented products. In most cases, fungal fermentation of cassava pulp has been carried out according to the solid-state fermentation method. This fermentation method is characterized by the low content of moisture in the substrates (Sugiharto and Rajitkar, 2019). Indeed, there is no specific reason on why solid state fermentation is more attracted to be employed in the fungal fermentation of cassava pulp. Yet, Gowthaman et al. (2001) suggested that solid-state fermentation may better support the fungi to grow on complex natural solid substrates without substantial pretreatment.

Table 2. Nutritional characteristics of fungal fermented cassava pulp

\begin{tabular}{|c|c|c|c|}
\hline References & $\begin{array}{l}\text { Microorganisms } \\
\text { involved in fermentation }\end{array}$ & $\begin{array}{l}\text { Supplement in } \\
\text { fermentation }\end{array}$ & Characteristics of fermented cassava pulp \\
\hline Lubis et al. (2007) & Aspergillus niger & None & $\begin{array}{l}\text { Crude protein content increased from } 2.21 \text { to } 3.58 \% \text { and } \\
\text { crude fibre increased from } 11.2 \text { to } 17.0 \%\end{array}$ \\
\hline Animashahun et al. (2013) & Penicillium spp. & None & $\begin{array}{l}\text { Crude protein increased from } 2.39 \text { to } 3.25 \% \text { and crude } \\
\text { fibre decreased from } 11.4 \text { to } 9.63 \% \text { after } 7 \text { days of } \\
\text { fermentation }\end{array}$ \\
\hline Bayitse et al. (2015) & $\begin{array}{l}\text { Trichoderma } \\
\text { pseudokoningii (ATCC } \\
\text { 26801) }\end{array}$ & $\begin{array}{l}\text { Urea and } \\
\text { ammonium } \\
\text { sulphate }\end{array}$ & $\begin{array}{l}\text { Protein content increased by } 48.1 \% \text { and } 36.9 \% \text { with } \\
\text { supplementation of urea and ammonium sulphate, } \\
\text { respectively }\end{array}$ \\
\hline Sugiharto et al. (2015) & Acremonium charticola & None & $\begin{array}{l}\text { Crude fibre decreased from } 18.4 \% \text { to } 16.9 \% \text {, while crude } \\
\text { protein did not significantly change (compared to } \\
\text { unfermented cassava pulp) }\end{array}$ \\
\hline Sugiharto et al. (2016) & A. charticola & Urea & $\begin{array}{l}\text { Crude protein increased from } 2.14 \% \text { to } 11.3 \% \text {, while crude } \\
\text { fibre decreased from } 25.6 \% \text { to } 20.8 \%\end{array}$ \\
\hline Sugiharto et al. (2016) & R. oryzae & Urea & $\begin{array}{l}\text { Crude protein increased from } 2.14 \% \text { to } 12.8 \% \text {, while crude } \\
\text { fibre decreased from } 25.6 \% \text { to } 22.7 \%\end{array}$ \\
\hline $\begin{array}{l}\text { Sengxayalth and Preston } \\
\text { (2017) }\end{array}$ & Saccharomyces cerevisiae & $\begin{array}{l}\text { Urea and di- } \\
\text { ammonium } \\
\text { phosphate }\end{array}$ & $\begin{array}{l}\text { Crude protein increased from } 9.5 \text { to } 18.4 \% \text { and true protein } \\
\text { increased from } 2 \text { to } 12 \% \text { dry matter }\end{array}$ \\
\hline Okrathok et al. (2018) & A. oryzae & Urea & $\begin{array}{l}\text { Crude protein increased from } 1.98 \% \text { to } 13.3 \% \text {, true protein } \\
\text { increased from } 0.98 \% \text { to } 12.4 \% \text { and crude fibre decreased } \\
\text { from } 13.6 \% \text { to } 10.7 \%\end{array}$ \\
\hline Yafetto (2018) & A. niger & $\begin{array}{l}\text { Ammonium } \\
\text { nitrate }\end{array}$ & Crude protein increased by $22.61 \%$ \\
\hline
\end{tabular}

\section{The use of fungal FCP in chicken diets}

Fungal fermentation has been attributed to the improved nutritional qualities of cassava pulp. As a consequence, fermentation can increase the inclusion levels of cassava pulp in chicken rations. As shown in Table 3, FCP may be included in broiler and laying hen rations greater than that of unfermented cassava pulp. However, the levels of FCP inclusion may vary from study 
to studies depending on the nutritional qualities of FCP, dietary composition and other experimental conditions. In most cases, there is a positive correlation between nutrient digestibility and feed intake in chickens (Sundu et al., 2006). In light with this, the improved nutritional qualities in FCP (especially the reduced fibre content) may be attributed to the reduced bulkiness and increased digestibility and thereby increased feed intake in chickens (Khempaka et al., 2014). Fermentation has been suggested to improve the palatability of products (Supriyati et al., 2015). In this respect, better palatability of FCP may be one of the reasons for the increased FCP intake in chickens when compared with the intake of unfermented cassava pulp. The toxicology of liver due to urea supplementation (during fermentation process) and the presence of toxic compounds such as $\mathrm{HCN}$ in cassava pulp may be a crucial point of consideration when using FCP as a dietary ingredient for chickens. In conjunction with Khempaka et al. (2014), we assessed the activities of aspartate aminotransferase (AST) and alanine aminotransferase (ALT) as indicators of liver health and found no change in the activities of these enzymes when feeding FCP as compared to control (Sugiharto et al., 2017b). The bioconversion of urea to fungal biomass protein (Bayitse et al., 2015) and the destruction of HCN during the fermentation process (Diarra and Devi, 2010) may implicate in safe inclusion of FCP in chicken diets.

Table 3. The levels of FCP inclusion in chicken rations

\begin{tabular}{ll}
\hline References & Recommended levels of FCP inclusion \\
\hline Lubis et al. (2007) & $\begin{array}{l}\text { A. niger-FCP-urea-zeolite may be used in diets up to 15\% without negative impacts on growth } \\
\text { performance and health of broilers. }\end{array}$ \\
\hline Ali-Mursyid et al. (2010) & $\begin{array}{l}\text { FCP could be included in diets up to } 16.5 \% \text { without detrimental effects on growth performance and } \\
\text { nutrient digestibility of broiler chicks. }\end{array}$ \\
\hline Khempaka et al. (2014) & $\begin{array}{l}\text { A. oryzae-FCP can be included up to 16\% in the rations with no deleterious effects on nutrient } \\
\text { digestibility and retention, final body weight, carcass traits and biochemical parameters. }\end{array}$ \\
\hline Sugiharto et al. (2017a) & $\begin{array}{l}\text { A. charticola-FCP can be included up to 16\% with no adverse effects on final body weight, } \\
\text { digestibility and carcass characteristics of broiler chickens }\end{array}$ \\
\hline Okrathok et al. (2018) & $\begin{array}{l}\text { A. oryzae-FCP was safe to be included up to 24\% in diets without deleterious effects on nutrient } \\
\text { digestibility, egg production and quality and physiological conditions of laying hens }\end{array}$ \\
\hline
\end{tabular}

\section{Functional properties of FCP as a dietary component in chicken diets}

Fermented products have been attributed to functional properties such as higher lactic acid bacteria (LAB) and organic acids contents. These properties make FCP beneficial for the health of the gastrointestinal tract of chickens (Sugiharto and Ranjitkar, 2019). Regarding to the effect of FCP on chicken health, the published data are still scarce. A recent study by our research group revealed that A. charticola-FCP decreased coliform bacteria count in the ileum and increased butyric and propionic acid concentrations in cecal contents of broiler chickens (Sugiharto et al., 2017a). The capacity of LAB and organic acids in controlling the proliferation of potentially pathogenic bacteria such as coliform may be responsible for the reduced population of such pathogenic bacteria in the intestine of chickens fed FCP. To increase the functionality of fermented products, fermentation using probiotic microorganisms (as starter inoculum) has been conducted (Sugiharto and Ranjitkar, 2019). In this respect, fermented products may not only have improved nutritional qualities, but also contain higher numbers of probiotic microorganisms. Due to the limited data, the study on the functional effect of FCP on chickens needs to be extensively conducted.

\section{CONCLUSION}

Solid-state fermentation using fungi can be a simple method to improve the nutritional qualities of cassava pulp and thus increase the inclusion level of such cheap agroindustrial by-product in chicken rations. Further studies are needed to explore the functional benefit of FCP on chicken health.

\section{DECLARATIONS}

\section{Acknowledgments}

Author acknowledges the support by Diponegoro University, Semarang Central Java, Indonesia through non-tax state revenue. 


\section{Competing interest}

I have no conflict of interest.

\section{Consent to publish}

I gave my consent prior to publication of this article.

\section{REFERENCES}

Ali-Mursyid WM, Bachruddin Z, Zuprizal and Nur-Cahyanto M (2010). Corn substitution using fermented solid cassavawaste on broiler chicken. Journal of the Indonesian Tropical Animal Agriculture, 35 (1): 9-15. DOI: 10.14710/jitaa.35.1.9-15

Animashahun RA, Omoikhoje SO, Edokpayi MI and Adesina BT (2013). Nutrient values of cassava residual pulp as affected by solid-state fermentation with Penicillium spp. International Journal of Applied Agricultural and Apicultural Research, 9 (1\&2): 42-47.

Asadollahzadeh M, Ghasemian A, Saraeian A, Resalati H and Taherzadeh MJ (2018). Production of fungal biomass protein by filamentous fungi cultivation on liquid waste streams from pulping process. BioResources, 13 (3): 50135031 .

Bayitse R, Hou X, Laryea G and Bjerre A-B (2015). Protein enrichment of cassava residue using Trichoderma pseudokoningii (ATCC 26801). AMB Express, 5 (80). DOI: $10.1186 / \mathrm{s} 13568-015-0166-8$

Bhardwaj V, Degrassi G and Bhardwaj RK (2017). Bioconversion of cellulosic materials by the action of microbial cellulases. International Research Journal of Engineering and Technology, 4 (8): 494-503.

Chauynarong N, Bhuiyan MM, Kanto U and Iji PA (2015). Variation in nutrient composition of cassava pulp and its effects on in vitro digestibility. Asian Journal of Poultry Science. 9 (4): 203-212. DOI: 10.3923/ajpsaj.2015.203.212

Chauynarong N, Iji PA and Kanto U (2010). The optimum level of cassava pulp in diets for layers. Proceeding of $21^{\text {st }}$ Australian Poultry Science Symposium, pp: 136-139.

Diarra SS and Devi A (2015). Feeding value of some cassava byproducts meal for poultry: A review. Pakistan Journal of Nutrition, $14 \quad$ (10): $735-741$. DOI: 10.3923/pjn.2015.735.741

Gowthaman MK, Krishna C and Moo-Young M (2001). Fungal solid state fermentation - an overview. Applied Mycology and Biotechnology, 1: 305-352. DOI: 10.1016/S18745334(01)80014-9

Khempaka S, Hokking L and Molee W (2016). Potential of dried cassava pulp as an alternative energy source for laying hens. Journal of Applied Poultry Research, 25: 359-369. DOI: 10.3382/japr/pfw020

Khempaka S, Maliwan P, Okrathok S and Molee W (2018). Digestibility, productive performance, and egg quality of laying hens as affected by dried cassava pulp replacement with corn and enzyme supplementation. Tropical Animal Health and Production, 50: 1239-1247. DOI: 10.1007/s11250-018-1550-6

Khempaka S, Molee W and Guillaume M (2009). Dried cassava pulp as an alternative feedstuff for broilers: Effect on growth performance, carcass traits, digestive organs, and nutrient digestibility. Journal of Applied Poultry Research, 18: 487-493. DOI: 10.3382/japr.2008-00124

King AJ and Zeidler G (2004). Tomato pomace may be a good source of vitamin $\mathrm{E}$ in broiler diets. California Agriculture, 58 (1): 59-62. DOI: 10.3733/ca.v058n01p59

Kumsri P, Ruangpanit Y, Attamangkune S, Songsermn O and Amornthewaphet N (2009). Effect of cassava pulp level and feed form on performance in broiler. Proceeding of the 47th Kasetsart University Conference: Animals, Bangkok, Thailand, pp: 132-140.

Lubis AD, Suhartono, Darmawan B, Ningrum H, Noormasari IY and Nakagoshi N (2007). Evaluation of fermented cassava (Manihot esculenta Crantz) pulp as a feed ingredient for broiler. Tropics, 17 (1): 73-80. DOI: 10.3759/tropics.17.73

Morgan NK and Choct M (2016). Cassava: Nutrient composition and nutritive value in poultry diets. Animal Nutrition, 2: 253-261. DOI: 10.1016/j.aninu.2016.08.010

Mustafa AM, Poulsen TG and Sheng K (2016). Fungal pretreatment of rice straw with Pleurotus ostreatus and Trichoderma reeseito enhance methane production under solid-state anaerobic digestion. Applied Energy, 180: 661-671. DOI: 10.1016/j.apenergy.2016.07.135

Okrathok S, Pasri P, Thongkratok R, Molee W and Khempaka S (2018). Effects of cassava pulp fermented with Aspergillus oryzae as a feed ingredient substitution in laying hen diets. Journal of Applied Poultry Research, 27: 188-197. DOI: 10.3382/japr/pfx057

Sengxayalth P and Preston TR (2017). Fermentation of cassava (Manihot esculenta Crantz) pulp with yeast, urea and diammonium phosphate (DAP). Livestock Research for Rural Development 29 (9). http://www.lrrd.org/lrrd29/9/pom29177.html

Sugiharto S and Ranjitkar S (2019). Recent advances in fermented feed towards improved broiler chicken performance, gastrointestinal tract microecology and immune responses: A review. Animal Nutrition. DOI: 10.1016/j.aninu.2018.11.001

Sugiharto S, Yudiarti T, Isroli I, Widiastuti E and Putra FD (2017b). Intestinal microbial ecology and hematological parameters of broiler fed cassava waste pulp fermented with Acremonium charticola, Veterinary World, 10 (3): 324-330. DOI: 10.14202/vetworld.2017.324-330

Sugiharto S, Yudiarti T, Isroli I, Widiastuti Eand Putra FD (2017a). Effects of feeding cassava pulp fermented with Acremonium charticola on growth performance, nutrient digestibility and meat quality of broiler chicks. South African Journal of Animal Science, 47 (2): 103-138. DOI: 10.4314/sajas.v47i2.4B.

Sugiharto S, Yudiarti T and Isroli I (2015). Functional properties of filamentous fungi isolated from the Indonesian fermented dried cassava, with particular application on poultry. Mycobiology, 43 (4): 415-422. DOI: 10.5941/MYCO.2015.43.4.415

Sugiharto S, Yudiarti T, Isroli I (2016). Haematological and biochemical parameters of broilers fed cassava pulp fermented with filamentous fungi isolated from the Indonesian fermented dried cassava. Livestock Research for Rural Development, 28 (4). http://www.lrrd.org/lrrd28/4/sugi28053.html 
Sundu B, Kumar A and Dingle J (2006). Response of broiler chicks fed increasing levels of copra meal and enzymes. International Journal of Poultry Science, 5 (1): 13-18. DOI: 10.3923/ijps.2006.13.18

Supriyati, Haryati T, Susanti T and Susana IWR (2015). Nutritional value of rice bran fermented by Bacillus amyloliquefaciens and humic substances and its utilization as a feed ingredient for broiler chickens. AsianAustralasian Journal of Animal Sciences, 28 (2): 231-238. DOI: 10.5713/ajas.14.0039

Tang DF, Ru YJ, Song SY, Choct M and Iji PA (2012). The effect of cassava chips, pellets, pulp and maize-based diets on performance, digestion and metabolism of nutrients for broilers. Journal of Animal and Veterinary Advances, 11 (9): 1332-1337. DOI: 10.3923/javaa.2012.1332.1337
Thongkratok R, Khempaka S and Moole W (2010). Protein enrichment of cassava pulp using microorganisms fermentation techniques for use as an alternative animal feedstuff. Journal of Animal and Veterinary Advance, 9 (22): 2859-2862. DOI: 10.3923/javaa.2010.2859.2862

Triprugsachart S, Ruangpanit Y, Attamanegkune S, Songserm O and Rattanatabtimtong S (2007). Effect of cassava pulp level on laying hen performance and egg quality. Proceeding of the 47th Kasetsart University Conference: Animals, Bangkok, Thailand. pp: 165-173.

Yafetto L (2018). Protein enrichment of cassava pulp by solidstate fermentation using Aspergillus niger. Studies in Fungi, 3(1): 7-18. DOI: 10.5943/sif/3/1/2 